\title{
Front Matter: Volume 11161
}

, "Front Matter: Volume 11161," Proc. SPIE 11161, Technologies for Optical Countermeasures XVI, 1116101 (1 November 2019); doi: 10.1117/12.2556192

SPIE. Event: SPIE Security + Defence, 2019, Strasbourg, France 


\section{PROCEEDINGS OF SPIE}

\section{Technologies for Optical Countermeasures XVI}

David H. Titterton

Robert J. Grasso

Mark A. Richardson

Editors

10-11 September 2019

Strasbourg, France

Sponsored and Published by

SPIE

Cooperating Organisations

European Optical Society

Cranfield University (United Kingdom) 
The papers in this volume were part of the technical conference cited on the cover and title page. Papers were selected and subject to review by the editors and conference program committee. Some conference presentations may not be available for publication. Additional papers and presentation recordings may be available online in the SPIE Digital Library at SPIEDigitallibrary.org.

The papers reflect the work and thoughts of the authors and are published herein as submitted. The publisher is not responsible for the validity of the information or for any outcomes resulting from reliance thereon.

Please use the following format to cite material from these proceedings:

Author(s), "Title of Paper," in Technologies for Optical Countermeasures XVl, edited by David H. Titterton, Robert J. Grasso, Mark A. Richardson, Proceedings of SPIE Vol. 11161 (SPIE, Bellingham, WA, 2019) Seven-digit Article CID Number.

ISSN: 0277-786X

ISSN: 1996-756X (electronic)

ISBN: 9781510630253

ISBN: 9781510630260 (electronic)

Published by

SPIE

P.O. Box 10, Bellingham, Washington 98227-0010 USA

Telephone +1 3606763290 (Pacific Time) · Fax +1 3606471445

SPIE.org

Copyright @ 2019, Society of Photo-Optical Instrumentation Engineers.

Copying of material in this book for internal or personal use, or for the internal or personal use of specific clients, beyond the fair use provisions granted by the U.S. Copyright Law is authorized by SPIE subject to payment of copying fees. The Transactional Reporting Service base fee for this volume is $\$ 21.00$ per article (or portion thereof), which should be paid directly to the Copyright Clearance Center (CCC), 222 Rosewood Drive, Danvers, MA 01923. Payment may also be made electronically through CCC Online at copyright.com. Other copying for republication, resale, advertising or promotion, or any form of systematic or multiple reproduction of any material in this book is prohibited except with permission in writing from the publisher. The CCC fee code is $0277-$ $786 \times / 19 / \$ 21.00$.

Printed in the United States of America by Curran Associates, Inc., under license from SPIE.

Publication of record for individual papers is online in the SPIE Digital Library.

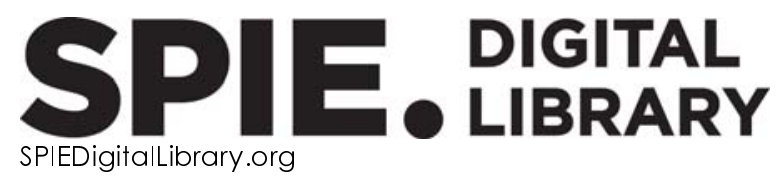

Paper Numbering: Proceedings of SPIE follow an e-First publication model. A unique citation identifier (CID) number is assigned to each article at the time of publication. Utilization of CIDs allows articles to be fully citable as soon as they are published online, and connects the same identifier to all online and print versions of the publication. SPIE uses a seven-digit CID article numbering system structured as follows:

- The first five digits correspond to the SPIE volume number.

- The last two digits indicate publication order within the volume using a Base 36 numbering system employing both numerals and letters. These two-number sets start with 00, 01, 02, 03, 04, 05, 06, 07, 08, 09, 0A, OB ... 0Z, followed by 10-1Z, 20-2Z, etc. The CID Number appears on each page of the manuscript. 


\title{
Contents
}

\author{
$\checkmark \quad$ Authors \\ vii Conference Committee
}

KEYNOTE SESSION

1116102 Quantum cascade lasers: 25 years after the first demonstration (Keynote Paper) [11161-1]

\section{LASERS AND SOURCES}

1116104 Investigations of incoherent beam combining using stochastic parallel gradient descent with retroreflector target [1 $111161-3]$

1116105 Fundamental mode emission in tapered quantum cascade lasers for high brightness [1 1161-4]

ATMOSPHERIC EFFECT

1116107 Characterization and compensation of atmospheric effects on laser beams (Invited Paper) [11161-6]

\section{LASER EFFECTS}

1116108 Mitigation of laser dazzle effects on a mid-wave infrared thermal imager by reducing the integration time of the focal plane array [1 $1161-7]$

1116109 Use of complementary wavelength bands for laser dazzle protection (Invited Paper) [1 $1161-8$ ]

$111610 \mathrm{~A} \quad$ Further investigation on laser-induced damage thresholds of camera sensors and microoptomechanical systems [1 $1161-9]$

$11161 \mathrm{OB}$ Wave-optics modeling of a heat-seeking missile attacked using a DIRCM laser in turbulent atmosphere (Invited Paper) [11161-10]

11161 OC NATO SET-249 joint measurement campaign on laser dazzle effects in airborne scenarios (Invited Paper) [11161-11] 
THREAT DETECTION AND IMAGING

$111610 G \quad$ Laser detection utilizing coherence (Invited Paper) [11161-15]

$11161 \mathrm{OH} \quad$ Developments in low-cost laser detection: wide field of view implementation and direction determination [1 $11161-16]$

$111610 \mathrm{O} \quad$ Remote detection and size estimation of optical apertures (Invited Paper) [11161-17]

$111610 \mathrm{~J} \quad$ Optics detection using an avalanche photo diode array and the scanning-slit-method [11161-18]

\section{THREATS, THREAT DETECTION, AND DISCRIMINATION}

11161 OK Mueller matrix characterization of samples for potential use in clutter rejection and discrimination algorithms (Invited Paper) [111161-19]

$11161 \mathrm{OL} \quad$ Novel low-cost camera-based pulsed and modulated continuous wave laser detection [11161-20]

\section{POSTERS-TUESDAY}

$111610 \mathrm{O}$ A new design method for a refractive beam shaping optical system operating in mid-infrared band [1 $1161-14]$

$111610 N \quad$ Research on optimization of water spray coverage of built-in infrared stealth water curtain single nozzle [1 $11161-21]$ 


\title{
Authors
}

Numbers in the index correspond to the last two digits of the seven-digit citation identifier (CID) article numbering system used in Proceedings of SPIE. The first five digits reflect the volume number. Base 36 numbering is employed for the last two digits and indicates the order of articles within the volume. Numbers start with 00, 01, 02, 03, 04, 05, 06, 07, 08, 09, 0A, OB...0Z, followed by 10-1Z, 20-2Z, etc.

\author{
Allard, Lars, 0J \\ Barron-Jimenez, Rodolfo, 02 \\ Başaran, Ahmet, $0 \mathrm{M}$ \\ Benton, David M., OG, OH \\ Bodrucki, F., OK \\ Boreman, G., OK \\ Bozat, Özgür, OB \\ Bozbulut, Ali Riza, OB \\ Brännlund, Carl, 04 \\ Chen, Zhongwei, ON \\ Davis, Christopher C., 07 \\ Eberle, Bernd, 09, 0C \\ Ericson, Bengt, ol \\ Ferlic, Nathaniel A., 07 \\ Figen, Ziya Gürkan, OB, OM \\ Fu, Yunpeng, ON \\ Henriksson, Markus, 04, 0J \\ Kinerk, Wesley T., OC \\ $\mathrm{Ko}$, Jonathan, 07 \\ Koerber, Michael, 0C \\ Köhler, Pontus, 0J \\ Lewis, G. D., 08 \\ Masselink, W. T., 05 \\ Öhgren, Johan, OC \\ Patel, C. Kumar N., 02 \\ Paulson, Daniel A., 07 \\ Pettersson, Magnus, $0 \mathrm{~J}$ \\ Ritt, Gunnar, 09, 0C \\ Rzasa, John R., 07 \\ Santos, Cristiane N., 08, 0C \\ Schwarz, Bastian, 0C \\ Semtsiv, M. P., 05 \\ Sjökvist, Lars, OJ \\ Steinvall, Ove, 0C, 01 \\ Sugden, Kate, $\mathrm{OG}, \mathrm{OH}$ \\ Svedbrand, Daniel, oJ \\ Tang, Xingji, ON \\ Tipper, Sean M., OC \\ Troccoli, Mariano, 02 \\ van lersel, Miranda, 07 \\ Vandewal, Marijke, 08, 0C \\ Westgate, Christopher L., OC \\ Wu, Chensheng, 07 \\ Yasa, Utku Görkem, OB \\ Zandi, Marie A., OG, $\mathrm{OH}$
}


Proc. of SPIE Vol. $111611116101-6$

Downloaded From: https://www.spiedigitallibrary.org/conference-proceedings-of-spie on 25 Apr 2023 Terms of Use: https://www.spiedigitallibrary.org/terms-of-use 


\title{
Conference Committee
}

\author{
Symposium Chairs
}

Ric Schleijpen, TNO Defense, Security and Safety (Netherlands)

Karin U. Stein, Fra unho fer-Institut für Optronik, Systemtechnik und Bildauswertung (Gemany)

Symposium Co-chair

Catherine Barrat, HGH Systèmes Infra rouges (France)

Conference Chairs

David H. Titterton, UK Defence Academy (United Kingdom)

RobertJ. Grasso, NASA Goddard Space Flight Center (United States)

Mark A. Richardson, Cranfield University (United King dom)

Conference Program Committee

Frances Bodrucki, The University of North Ca rolina at C harlotte (United States)

Christopher D. Burgess, Defence Science and Technology Laboratory

(United King dom)

Brian Butters, Meon Technology Limited (United Kingdom)

StuartN. Chapman, Leona rdo S.p.A. (United Kingdom)

Marc Eichhom, Fra unho fer-Institut für Optronik, Systemtechnik und Bildauswertung (France)

lan F. Elder, SELEX Ga lileo Ltd. (United Kingdom)

Markus Henriksson, FOI-Sw edish Defence Research Agency (Sweden)

David B. James, Cranfield University (United Kingdom)

ItorJames, Defence Science and Technology Laboratory (United Kingdom)

Helena Jelinkova, Czech Technical University in Prague (C zech Republic)

Gerald C. Manke II, Naval Surface Warfare Center Crane Division (United States)

Eric D. Park, Q-Peak, Inc. (United States)

Manijeh Razeghi, Northw estem University (United States)

Ric H. M. A. Schleijpen, TNO Defence, Security and Safety (Netherlands)

Dirk Peter Seiffer, Fraunhofer-Institut für Optronik, Systemtechnik und Bild a usw ertung (Gemany)

Ove Steinvall, Swedish Defence Research Agency (Sweden) 
Alexander M. J. van Eijk, TNO Defence, Security and Safety (Netherlands)

Dorota S. Temple, RTI Intemational (United States)

Hans-Dieter Tholl, Diehl BGT Defence GmbH \& Company KG (Germany)

Marijke Vandewal, Royal Military Academy (Belgium)

\section{Session Chairs}

1 Keynote Session

RobertJ. Grasso, NASA Goddard Space Flight Center (United States)

2 La sers and Sources

David H. Titterton, Cranfield Defence and Security (United Kingdom)

3 Atmospheric Effect

Ove Steinvall, FOI-Swedish Defence Research Agency (Sweden)

$4 \quad$ La ser Effects

Hans Dieter Tholl, Diehl Defence GmbH \& Company KG (Germany)

5 Optics and Optical Systems

Frances Bodrucki, U.S. Army (United States)

6 Threat Detection and Imaging

Eric D. Park, Q-Peak, Inc. (United States)

7 Threats, Threat Detection, and Discrimination

Dorota S. Temple, RTI Intemational (United States) 